\title{
REPRESENTASI LAKI-LAKI METROSEKSUAL DALAM IKLAN VASELINE MEN FACE MOISTURIZER
}

\author{
Arnie Mellawatie, Eni Maryani, Nindi Aristi \\ Universitas Padjajaran
}

\begin{abstract}
ABSTRAK
Penelitian ini bertujuan untuk mengetahui tentang perwakilan metroseksual dalam Vaseline Men Face Mousturizer TVC dari makna dennotasi dan konotasi, serta mengetahui perwakilan mitos metroseksual dalam Vaseline Men Face Mouisturizer TVC. Penelitian ini menggunakan metode semiotika oleh Roland Barthes. Analisis Semiotik diimplementasikan pada TVC (Televisi Komersial) versi Vaseline Men Face Moisturizer Darius Sinathrya. Analisis ini difokuskan pada adegan-adegan yang mengandung tanda-tanda dominan metroseksual. Hasil penelitian menemukan karakteristik pria metroseksual yang terkandung dalam iklan Vaseline Men Face Moisturizer. Tanda yang dapat diartikan sebagai kebiasaan pria metroseksual adalah pria yang memiliki tubuh atletis dan berolahraga di pusat kebugaran, pria yang memiliki kulit wajah cerah dan tidak memiliki noda hitam, pria yang menggunakan produk kosmetik, dan pria metroseksual yang menjadi idola pria. Berdasarkan analisis tanda-tanda denotasi dan konotasi, yang dilakukan oleh para peneliti, ditemukan bahwa mitos metroseksual adalah mitos maskulinitas dalam konsep metroseksual, dan mitos pria metroseksual adalah idola pria.
\end{abstract}

Kata-kata Kunci: Metroseksual, Representasi Metroseksual, Seiotik Roland Barthes

\section{REPRESENTATION OF METROSEXUAL MENS IN VASELINE MEN FACE MOISTURIZER ADS}

\begin{abstract}
This research is aimed to know about the representatives of metrosexual in Vaseline Men Face Mousturizer TVC from dennotation and connotation meaning, and also to know the representatives of metrosexual myth in Vaseline Men Face Mouisturizer TVC.This research using methods of semiotics by Roland Barthes. The Semiotic analysis implemented on TVC (Television Commercial) Vaseline Men Face Moisturizer Darius Sinathrya version. This analysis focused on the scenes which containing a dominant signs of metrosexual.The results of the research find characteristics of metrosexsual men contained in Vaseline Men Face Moisturizer advertising. Signs that can be interpreted as habitude of metrosexsual men is a man who have an athletic bodies and workout in the fitness center, men who have bright facial skin and doesn't have a black stain, men that using cosmetics product, and metrosexual male who become male idol. Based on analysis of denotation and connotation signs, conducted by researchers, it was found that the metrosexual myths are masculinity myth in the metrosexual concept, and the myth of metrosexual male are male idol.
\end{abstract}

Keywords: Metrosexual, Representation of Metrosexual, Semiotic by Roland Barthes.

Korespondensi: Ernie Mellawatie. Universitas Padjadjaran. Jl. Raya Bandung Sumedang KM.21, Hegarmanah, Jatinangor, Kabupaten Sumedang, Jawa Barat 45363 Email:arniemellawatie@gmail.com 


\section{PENDAHULUAN}

Di dalam iklan Vaseline Men Face Moisturizer versi Darius Sinathrya terdapat adegan dimana Darius Sinathrya bersama seorang laki-laki bernama Hardy Hartono sedang berjalan menghampiri seorang laki-laki lain setelah melakukan kegiatan fitness. Hardy Hartono yang sedang bercermin dikatakan memiliki kulit yang kusam oleh laki-laki tersebut, kemudian Hardy Hartono menyatakan diri dengan membandingkan dirinya terhadap Darius Sinathrya yang memiliki wajah yang lebih bersih dan terawat, Hardy Hartono menganggap Darius Sinathrya memiliki wajah yang tampan rupawan semenjak dilahirkan, pernyataan itu kemudian disangkal oleh Darius yang menyatakan bahwa kulit muka yang ia miliki saat ini, dikarenakan ia merawat dirinya dengan menggunakan produk Vaseline Men Face Moisturizer dan Darius Sinathrya pun menyarankan kepada Hardy Hartono untuk menggunakan produk tersebut agar memiliki wajah yang terawat seperti dirinya.

Iklan "Vaseline Men Moisturizer" merupakan sebuah iklan produk perawatan diri bagi kaum pria, yang menampilkan konstruksi Darius Sinathrya sebagai seorang entertaintment muda bertubuh bidang dan berotot, dengan aktivitas tinggi dalam bidang pekerjaannya yaitu industri hiburan di Indonesia. Dengan begitu padatnya kegiatan, Darius Sinathrya tetap memiliki wajah tampan rupawan yang terawat. Di dalam iklan ini jelas diperlihatkan bahwa bukan hanya tubuh bidang dan berotot saja yang diperlukan untuk menarik dalam penampilan, namun juga diperlukan wajah rupawan dan terawat.

Dahulu jika seorang laki-laki yang menggunakan produk kosmetik perawatan diri maka laki-laki tersebut akan dianggap homoseksual, dan merupakan suatu hal tabu bagi seorang laki-laki yang kerap memperhatikan penampilannya dengan bersolek. Seorang laki-laki memiliki nilai maskulin di dalam dirinya, berbanding lurus dengan wanita yang memiliki nilai feminin didalam dirinya. Persilangan antara konsep maskulinitas dan feminitas pada akhirnya melahirkan konsep maskulinitas baru, yaitu konsep metroseksual.

Metroseksual adalah sebuah kata baru yang diperkenalkan oleh Mark Simpson dalam artikelnya yang diterbitkan harian The Independent, yang merupakan salah satu surat kabar paling berpengaruh di Inggris, pada tahun 1994. Di dalam artikelnya Mark Simpson menggambarkan laki-laki metroseksual adalah pria lajang dengan pendapatan berlebih yang hidup di kawasan perkotaan yang sangat mencintai dirinya dan juga gaya hidupnya, sehingga sangat peduli dengan penampilannya untuk memuaskan dirinya sendiri.

Untuk mengungkapkan apa yang direpresentasikan oleh suatu pesan, penelitian ini menggunakan analisis semiotika Roland Barthes yang menganalisis sebuah teks berdasarkan makna konotatif, makna denotatif, dan mitos seputar fenomena yang ada dalam iklan yang menjadi isu utama dalam penelitian ini. Selain itu kita dapat meganalisis mitos metroseksual yang ingin 
disampaikan dalam iklan Vaseline Men Face Moisturizer ini kepada masyarakat Indonesia. Penelitian ini mengambil judul Representasi Metroseksual Dalam Iklan Vaseline Men Face Moisturizer (Studi Semiotik Tentang Representasi Laki-laki Metroseksual Dalam Iklan Vaseline Men Face Moisturizer versi Darius Sinathrya).

\section{METODE}

Penelitian ini menggunakan pendekatan kualitatif. Yang dimaksud dengan pendekatan kualitatif adalah suatu pendekatan dalam melakukan penelitian yang beroriantasi pada gejala-gejala yang bersifat alamiah karena orientasinya demikian, maka sifatnya naturalistik dan mendasar atau bersifat kealamiahan serta tidak bisa dilakukan di laboratorium melainkan harus terjun di lapangan. Pendekatan kualitatif adalah suatu pendekatan yang tidak menggunakan analisis data statistik, karena data-data yang dikumpulkan berupa kata-kata atau gambar, bukan angka-angka.

Metode penelitian kualitatif ini menggunakan analisis semiotika model Barthes. Semiotika, atau dalam istilah Barthes, semiologi, pada dasarnya hendak mempelajari bagaimana kemanusiaan (humanity) memakai hal-hal (things). Memaknai (to sinify) dalam hal ini tidak dapat dicampuradukkan dengan mengkomunikasikan (to communicate). Memaknai berarti bahwa objekobjek tidak hanya membawa informasi, dalam hal mana objek-objek itu hendak berkomunikasi, tetapi juga menkonstitusi sistem terstruktur dari tanda (Barthes, 1988:179: Kurniawan, 2001:53).
Istilah semiotika dan semiologi mengandung pengertian yang sama persis, yang membedakan penggunaan salah satu dari kedua istilah ini adalah pemikiran pemakainya. Menurut Fiske (2010:60), semiotika memiliki tiga bidang studi utama:

Satu, tanda itu sendiri. Hal ini terdiri atas studi tentang berbagai tanda yang berbeda, cara tanda-tanda itu terkait dengan manusia yang menggunakannya. Tanda adalah konstruksi manusia dan hanya bisa dipahami dalam artian manusia yang menggunakannya.

Dua, kode atau sistem yang mengorganisasikan tanda. Studi ini mencangkup cara berbagai kode dikembangkan guna memenuhi kebutuhan suatu masyarakat atau budaya atau untuk mengeksploitasi saluran komunikasi yang tersedia untuk mentransmisikannya.

Tiga, kebudayaan tempat kode dan tanda bekerja. Ini pada gilirannya bergantung pada penggunaan kode-kode dan tanda-tanda itu untuk keberadaan dan bentuknya sendiri.

Ketiga bidang tersebut saling berkaitan dalam penelitian ini. dimana hal yang paling utama diamati dan diteliti dari penelitian ini adalah tanda, selanjutnya tanda-tanda tersebut berkembang dimasyarakat dan dimaknai sebagai sesuatu yang dapat mewakili, hal tersebutlah yang dapat dikatakan sebagai kode. Kode-kode tersebut dapat mewakili sesuatu yang ingin disampaikan dalam adegan iklan, yang disebut dengan kode representasi. Kebudayaan tempat kode itu bekerja juga akan mempengaruhi hasil akhir dari pemaknaan sebuah tanda, dimana akan terbentuk 
sebuah makna konotatif dan mitos. Mitos dan nilainilai konotatif adalah ideologi karena ideologi itulah maka mitos dan konotasi mewujudkan kegunaannya.

Penelitian ini menggunakan metode semiotika Roland Barthes untuk menganalisis tanda-tanda yang digunakan pada iklan Vaseline Men Face Moisturizer. Pemaknaan yang dilakukan dalam penelitian ini menggunakan metode analisis Roland Barthes yaitu identifikasi hubungan antar tanda, dimana hubungan antara petanda dan penanda pada signifikasi yang dipakai oleh Barthes dan berasal dari konsep Jakobson, terdiri atas: (a) metafora, biasanya dikaitkan dengan ungkapan yang berbau puitis dan menimbulkan emosi, sehingga menembus makna linguistik yang bekerja atas dasar hubungan paradigmatik. Metafora bukan hanya perangkat sastra, Lakoff dan Johnson (1980) menunjukkan metafora memiliki lebih banyak fungsi fundamental, yakni fungsi keseharian. Metafora merupakan bagian dari cara kita memahami pengalaman keseharian kita. Metafora keseharian berbeda dengan metafora sastra dalam beberapa hal. Metafora keseharian tidak untuk menarik perhatian pada metafora sendiri sebagai metafora, sehingga tidak melibatkan kita untuk men-decode-nya secara sadar. Metafora seperti itu dengan sendirinya lebih tersamar dan membuatnya jadi lebih mudah menjadi bagian dari "anggapan umum" masyarakat kita, karena itulah metafora menjadi bagian yang tak terperiksa, dan menjadi asumsi-asumsi yang siap dipakai yang menyebar luas ke segenap lapisan masyarakat. Anggapan umum seperti itu tampaknya alami, namun sebenarnya tak pernah seperti itu: anggapan umum selalu bersifat arbiter, selalu diproduksi secara sosial. Karena itulah, pada akhirnya, menjadi ideologis: kekuasan kelas dominan untuk sebagian dipelihara sampai pada tingkat gagasangagasannya menjadi anggapan umum semua kelas. (Fiske, 2010:127-130)

(b) Metonimi, muncul dari kesadaran logis dan bekerja secara sistematik. Dijelaskan bahwa metonimi adalah suatu fungsi yang melibatkan satu petanda untuk menjelaskan petanda lain yang memiliki hubungan erat dengan petanda tersebut. Bentuk metonimi juga merupakan asosiasi dari dua buah konsep yang memiliki makna sebagai untuk keseluruhan. Metomini merupakan pembawa realitas yang kuat karena metomini bekerja secara indeksikal. Metomini merupakan bagian dari apa yang ditunjukkannya. Tatkala metomini dibedakan dari indeks-indeks 'alami', seperti asap untuk api, maka seleksi yang sangat arbiter terjadi. Kearbiteran seleksi ini tersembunyi atau setidaknya diabaikan, dan metomini dibuat untuk menyingkapkan indeks alami sehingga bisa diberi status "nyata", atau "tak dipertanyakan". (Fiske, 2010:131-135)

\section{HASIL DAN PEMBAHASAN}

Dalam bab ini peneliti memaparkan hasil analisis iklan Vaseline Men Face Moisturaizer dengan menggunakan metode semiotika Roland Barthes, dimana dalam semiotika model Roland Barthes dijelaskan terdapat dua tingkatan penandaan yang memungkinkan untuk 
dihasilkannya makna, yaitu tingkat denotasi dan konotasi.

Semiotika Roland Barthes hampir memiliki kesamaan dengan teori bahasa yang dikembangkan oleh de Saussure. Saussure mengemukakan empat konsep teoretis, yakni konsep langue-parole, significant-signifie, sintagmatik-paradigmatik, dan sinkroni-diakroni. (Hoed, 2011:10). Dalam analisis struktur teks, Barthes menggunakan dua konsep yang relevan, yakni konsep hubungan sintagmatikparadigmatik, dan konsep denotasi-konotasi. (Hoed, 1994:11)

Untuk mengetahui makna-makna denotasi dan konotasi yang terkandung dalam beberapa adegan dalam Iklan Vaseline Men Face Moisturizer, maka yang akan dilaporkan peneliti adalah kode-kode yang merepresentasikan metroseksual dalam iklan tersebut. Dimana kodekode merupakan sistem pengorganisasian tanda (Fiske, 2010:91). Dan tanda-tanda tersebutlah yang merepresentasikan makna denotatif dan konotatif tersebut.

\section{Analisis Sintagmatik dan Paradigmatik}

Analisis sintagmatik melihat teks sebagai sebuah rangkaian dari satuan waktu dan tata ruang yang membentuknya. Sintagma ibarat suatu rantai, sehingga analisis sintagmatik berupaya melihat teks sebagai rangkaian peristiwa yang membentuk sejumlah narratives atau cerita (Berger, 1982:24). Dalam melakukan analisis sintagmatik, diperlukan beberapa tahapanan, yakni mendeskripsikan iklan Vaseline Men Face Moisturizer secara lengkap, lalu melakukan identifikasi adegan, dan melakukan analisis terhadap susunan adegan. Setelah melakukan analisis struktur sintagmatik teks, peneliti memilih scene 1, 2, 6 dan 11 pada iklan Vaseline Men Face Moisturizer, maka peneliti kemudian melakukan analisis paradigmatik terhadap tanda-tanda yang terdapat dalam scenescene tersebut.

Dari tanda-tanda yang terdapat dalam iklan Vaseline Men Face Moisturizer yakni lokasi, bentuk tubuh laki-laki, kulit wajah, produk kosmetik dan ketertarikan wanita pada laki-laki metroseksual, peneliti memilih kelima hal tersebut sebagai tanda penting yang membangun makna dan struktur teks terkait metroseksual. Pada iklan Vaseline Men Face Moisturizer versi Darius Sinathrya memiliki alur cerita atau narasi yakni, adegan dilakukan di lokasi fitness center, bentuk tubuh ideal yang dimiliki Darius Sinathrya, kulit wajah kusam dan bernoda hitam, penggunaan produk kosmetik Vaseline Men Face Moisturizer, dan ketertarikan wanita pada laki-laki dengan wajah terawat. Kelima tanda tersebut adalah tandatanda yang penting dalam membangun teks iklan.

\section{Representasi Dilihat Dari Makna Denotasi dan} Konotasi

Laki-laki Metroseksual Bertubuh Atletis dan Berolahraga di Fitness Center 


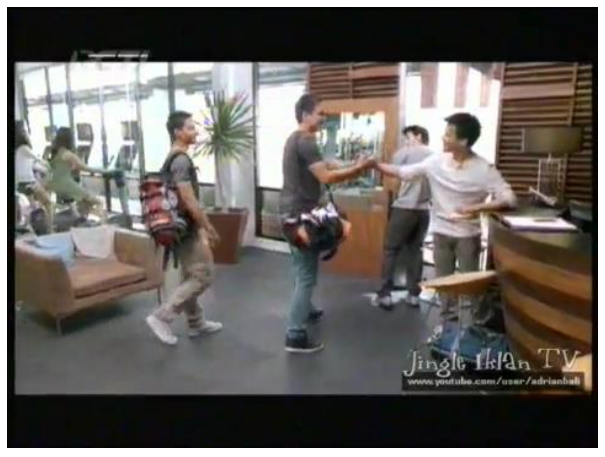

Makna Denotasi Dalam Scene ke-1

Petanda : Disebuah pusat kebugaran, Darius Sinathrya menjabat tangan seorang laki-laki sehingga memperlihatkan lengan tangannya yang berotot.

Penanda : Disebuah pusat kebugaran lakilaki pertama menjabat tangan laki-laki kedua sehingga memperlihatkan lengan tangan laki-laki pertama yang berotot.

Tanda : Disebuah pusat kebugaran Darius Sinathrya (laki-laki pertama) menjabat tangan seorang laki-laki (laki-laki kedua) sehingga memperlihatkan lengan tangannya (laki-laki pertama) yang berotot.

Berdasarkan analisis konotasi diatas, maka teks yang tergambar dalam scene ke-1 dapat dimaknai debagai berikut:

$\begin{array}{ccrr}\text { Bentuk } & \text { : Disebuah } & \text { pusat } & \text { kebugaran } \\ \text { Darius } & \text { Sinathrya } & \text { (laki-laki } \\ \text { pertama) } & \text { menjabat } & \text { tangan } \\ & \text { seorang } & \text { laki-laki } & \text { (laki-laki } \\ & \text { kedua) sehingga memperlihatkan }\end{array}$

lengan tangannya (laki-laki pertama) yang berotot.

Konsep : Laki-laki metroseksual bertubuh atletis dan berolahraga di fitness center.

\section{Laki-laki Metroseksual Berwajah Cerah dan Tak Bernoda Hitam}

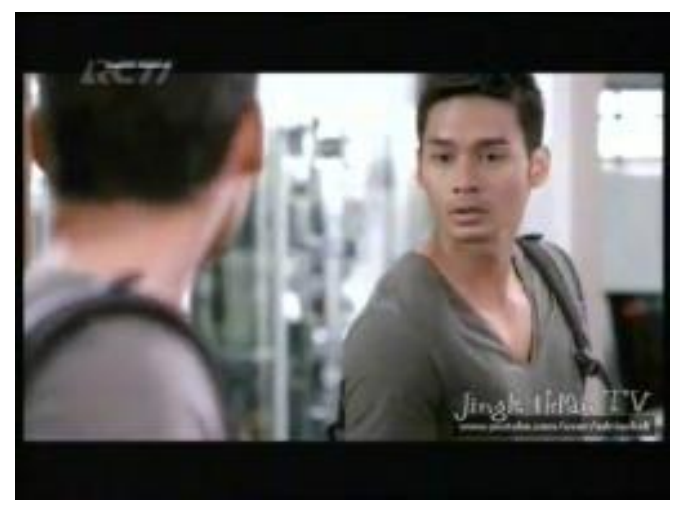

Makna Denotasi Dalam Scene Ke-2

Petanda : Hardy Hartono memiliki wajah kusam, berbeda dengan Darius Sinathrya yang memiliki wajah ganteng sejak lahir.

Penanda : Laki-laki pertama memiliki wajah kusam, berbeda dengan laki-laki kedua yang memiliki wajah ganteng sejak lahir.

Tanda

$$
\begin{aligned}
& \text { : Hardy Hartono (laki-laki } \\
& \text { pertama) memiliki wajah } \\
& \text { kusam, berbeda dengan (laki- } \\
& \text { laki kedua) Darius Sinathrya } \\
& \text { yang memiliki wajah ganteng } \\
& \text { sejak lahir. }
\end{aligned}
$$

Berdasarkan analisis konotasi diatas, maka teks yang tergambarkan dalam scene ke-2 dapat dimaknai sebagai berikut: 
Bentuk : Hardy Hartono (laki-laki pertama) memiliki wajah kusam berbeda dengan (laki-laki kedua) Darius Sinathrya yang memiliki wajah ganteng sejak lahir.

Konsep : Laki-laki metroseksual berwajah cerah dan tak bernoda hitam.
Bentuk : Darius Sinathrya (laki-laki) menggenggam kemasan Vaseline Men Face Moisturizer (produk perawatan wajah khusus pria).

Konsep : Laki-laki metroseksual sebagai konsumen produk kosmetik.

\section{Laki-laki Metroseksual sebagai Konsumen Produk Kosmetik}

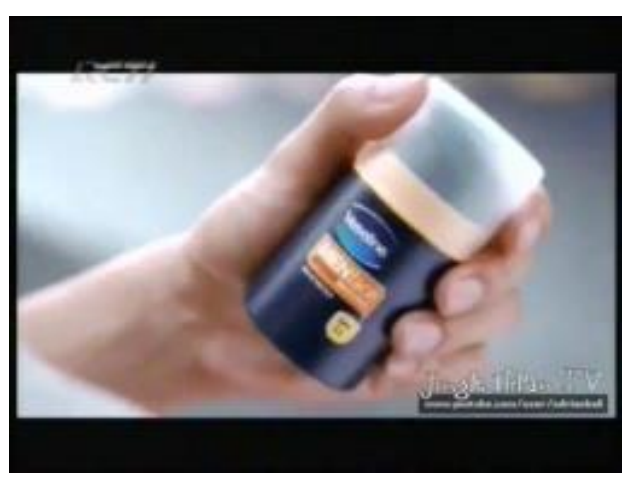

Makna Denotasi dalam Scene Ke-6
Petanda : Darius Sinathrya menggenggam kemasan produk Vaseline Men Face Moisturizer.

Penanda : Laki-laki menggenggam sebuah kemasan produk kosmetik perawatan wajah khusus pria.

Tanda : Darius Sinathrya (laki-laki) menggenggam kemasan produk Vaseline Men Face Moisturizer (produk kosmetik perawatan wajah khusus pria).

Berdasarkan analisis konotasi diatas, maka teks yang tergambar dalam scene Ke-6 dapat dimaknai sebagai berikut:

\section{Laki-laki Metroseksual Sebagai Tokoh Idola}

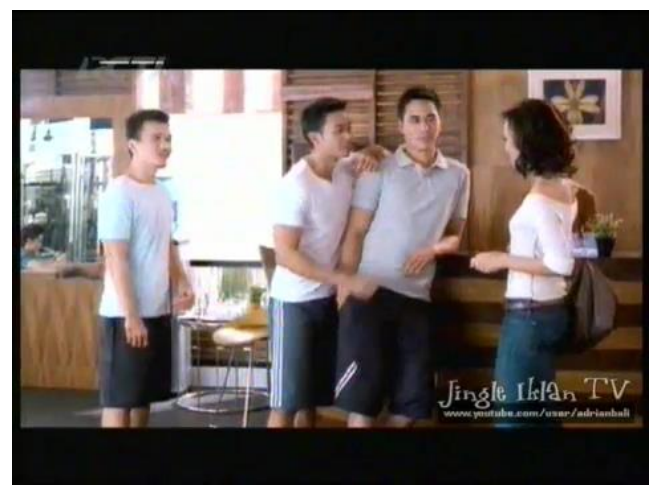

Makna Denotasi Dalam Scene ke-11

Petanda : Darius Sinathrya merupakan seorang artis.

Penanda : Laki-laki pertama merupakan public figure.

Tanda : Darius Sinathrya (laki-laki pertama) merupakan seorang artis (public figure).

Berdasarkan analisis konotasi diatas, maka teks yang tergambarkan dalam scene ke-11 dapat dimaknai sebagai berikut:

Bentuk : Darius Sinathrya (laki-laki pertama) merupakan seorang artis (public figure).

Konsep : Laki-laki metroseksual sebagai tokoh idola. 


\section{PENUTUP}

Peneliti menemukan bahwa terdapat dua mitos metroseksual yang dihasilkan dari iklan Vaseline Men Face Moisturaizer. Mitos yang ditemukan adalah mitos maskulinitas dalam konsep metroseksual dan mitos tokoh idola laki-laki metroseksual

\section{DAFTAR PUSTAKA}

Chandler, Daniel. 2000. Semiotics for Begginer. Wales. University of Wales.

Djurato dan Bambang Supriyadi.2003. Kamus Besar Bahasa Indonesia. Jakarta : Balai Pustaka

Eriyanto. 2009. Analisis Wacana Pengantar Analisis Teks Media. Yogyakarta: LKiS

Fiske, John. 2010. Cultural and Communication Studies: Sebuah Pengantar Paling Komprehensif. Bandung: Jalasutra

Gephart. 1999. Essential Guide to Qualitative methods in Organizational Research. London : SAGE Publication Ltd.

Hall, Stuart. 2003. Representation : Cultural Representations and Signifying Practices. London: SAGE Publication Ltd

Liliweri, Alo. 1992. Dasar-dasar Periklanan. Bandung. Citra Aditya Bakti.

Moleong, Lexi J. 2000. Metodelogi Penelitian Kualitatif. Bandung: Remaja Rosda Karya 2007. Metodelogi Penelitian Kualitatif. Bandung: Remaja Rosda Karya

Mulyana, Deddy. 1999. Nuansa-Nuansa Komunikasi. Bandung. PT. Remaja Rosdakarya.

Piliang, Yasraf Amir. 2010. Hipersemiotika: Tafsir Cultural studies Atas Matinya Makna. Bandung: Jalasutra
Purnomo, Edy. 2004. Dia dan Foto Siapa. Medan.

Sobur, Alex. 2002. Analisis Teks Media. Bandung: Remaja Rosda Karya.

Storey, John. 2010. Pengantar Komprehensif Teori dan Metode Cultural Studies dan Kajian Budaya Pop. Bandung: Jalasutra

Weber, Max. 1991. From Max Weber: Essay in Sociology. Inggris: Routledge

Wibowo, Wahyu. 2003. Sihir Iklan “ Format Komunikasi Mondial dalam Kehidupan Urban Kosmopolit”. Jakarta. PT Gramedia Pustaka Utama.

Widyatama, Rendra. 2996. Bias Gender : Dalam Iklan Televisi. Yogyakarta. Media Pressindo.

\section{Sumber Artikel :}

Jenis Olahraga Berdasarkan Tipe Tubuh. Diakses dari http://informasitips.com/jenisolahraga-berdasarkan-tipe-tubuh/

Cowok Dandan dan Wangi? Kenapa Tidak? Diakses dari: http://nostalgia.tabloidnova.com/articles.as p?id=8028/ (Diakses 06 Juni 2012)

Juliastuti, Nuraini. 2000. Kebudayaan yang Maskulin, Macho, Jantan, dan Gagah. Artikel dalam jurnal KUNCI "Maskulinitas" edisi 8 (September 2000). Diunduh dari http://www.archive.org/details/Newsletter $\underline{\text { Kunci8 Maskulinitas }}$

Simpson, Mark. Here some the mirror men.

Diakses dari: http://www.marksimpson.com/herecome-the-mirror-men/ 